\title{
Mugwort Control in an Abandoned Nursery Using Herbicides That Mimic Indole-3-Acetic Acid
}

\author{
Rebecca M. Koepke-Hill ${ }^{1,3}$, Gregory R. Armel ${ }^{1,4,9}$, \\ William E. Klingeman ${ }^{1,5}$, Mark A. Halcomb ${ }^{2,6}$, \\ Jose J. Vargas ${ }^{1,7}$, and Phillip C. Flanagan ${ }^{1,8}$
}

AdDitional INDEX wORDs. aminocyclopyrachlor-methyl, aminopyralid, Artemisia vulgaris, clopyralid, invasive weed, picloram, non-cropland, nursery crops.

SUMMARY. Field and greenhouse studies were conducted to determine if two indole3 -acetic acid herbicide mimics, aminopyralid and aminocyclopyrachlor-methyl, applied at 70,140 , and $280 \mathrm{~g} \cdot \mathrm{ha}^{-1}$ postemergence (POST) would control mugwort (Artemisia vulgaris) in an abandoned nursery. These were compared with the commercial standards picloram at $280 \mathrm{~g} \cdot \mathrm{ha}^{-1}$ a.i. and clopyralid at $280 \mathrm{~g} \cdot \mathrm{ha}^{-1}$. In the field study, picloram and clopyralid controlled mugwort $75 \%$ and $31 \%$ by 365 days after treatment (DAT), respectively. In contrast, aminopyralid and aminocyclopyrachlor-methyl applied at $140 \mathrm{~g} \cdot \mathrm{ha}^{-1}$ controlled mugwort over $90 \%$ by 365 DAT. In the greenhouse study, aminopyralid and aminocyclopyrachlor-methyl applied at $140 \mathrm{~g} \cdot \mathrm{ha}^{-1}$ controlled mugwort $92 \%$ and $96 \%$ respectively, although aminopyralid at $70 \mathrm{~g} \cdot \mathrm{ha}^{-1}$ provided better visual control (94\%) in comparison with aminocyclopyrachlor-methyl (79\%) at $70 \mathrm{~g} \cdot \mathrm{ha}^{-1}$. Regardless, following shoot growth removal at 30 DAT, mugwort failed to regrow by 60 DAT following exposures to all rates of both herbicides. On the basis of these studies, aminopyralid and aminocyclopyrachlormethyl have potential to provide excellent control of mugwort compared with the current standards clopyralid and picloram.

$\mathrm{M}$ ugwort has been reported in 56 countries as a highly invasive weed that has adapted to a broad range of climates (Holm et al., 1997). Mugwort persists in diverse soil types and can establish in both undisturbed and cultivated lands. Mugwort plants produce volatile allelochemicals that negatively impact surrounding vegetation by inhibiting growth and survival of other plant

The authors appreciate the samples of material provided by DuPont Crop Protection and Dow AgroSciences. The authors thank Greg Allen and Jake Huffer for their technical assistance with the field studies. The authors also appreciate the technical reviews of this manuscript by James Brosnan, Dean Kopsell, Dennis West, Amy Fulcher, and Annette Wszelaki. Finally, the authors recognize the late James Smartt who without his generous provisions of land, time, and talents this research would not have been possible.

${ }^{1}$ Department of Plant Sciences, The University of Tennessee, 2431 Joe Johnson Drive, 252 Ellington Plant Sciences Building, Knoxville, TN 37996

${ }^{2}$ University of Tennessee Extension, 201 Locust Street, Suite 10, McMinnville, TN 37110

${ }^{3}$ Extension Assistant.

${ }^{4}$ Assistant Professor.

${ }^{5}$ Associate Professor.

${ }^{6}$ Area Nursery Specialist.

${ }^{7}$ Research Assistant.

${ }^{8}$ Research Associate.

${ }^{9}$ Corresponding author. E-mail: garmel@utk.edu. seedlings (Barney et al., 2005). The highest concentrations of these allelochemicals are found in young leaves, thus giving young mugwort plants an advantage in establishing new populations. Mugwort propagates by both rhizome and seed, but seed viability appears to depend upon climatic conditions (Pawlowski et al., 1967). Over 200,000 viable seeds can be produced by one plant and most will germinate the following spring (Pawlowski et al., 1967). However, few viable seeds are produced in the eastern United States (Holm et al., 1997), thus rhizomes are the primary method of mugwort reproduction. Since mugwort plants can grow from $\approx 6-\mathrm{mm}$ long rhizomes; mechanical methods of control such as hand pulling or tilling are not desirable and may contribute to the spread of this species (Klingeman et al., 2004; Rogerson, 1964). In addition, Rogerson (1964) found that a $10-\mathrm{cm}$ shoot of mugwort could create $23 \mathrm{~m}$ of rhizomes in 4 months, thereby, further explaining the aggressive invasive nature of this species.

The invasive potential of mugwort is often favored by conditions created in nursery environments. Klingeman et al. (2004) found that as little as a $2-\mathrm{cm}$ fragment of mugwort rhizomes would regenerate $69 \%$ to $85 \%$ regardless of whether planted in soil, sand, or pine bark media. This adaptability to various soil types allows mugwort rhizomes intermingled with the roots of nursery stock to survive transplant between field and container production areas. Also, control of broadleaf weeds in container or field grown nursery plants is often limited to herbicides that have soil residual activity and must be applied before emergence of the target weed (Senseman, 2007). However, many of these residual herbicides have proven to be ineffective in controlling mugwort because they are not systemic or because those that have activity on mugwort can also have detrimental impacts to desirable nursery species (Danielson, 1965). Therefore, systemic herbicides, which are herbicides that translocate to the roots or rhizomes of susceptible weeds, are needed to limit reproduction and to ensure complete plant death of perennial plants like mugwort.

Herbicides that inhibit amino acid formation in plants and those which mimic indole-3-acetic acid are usually systemic in nature, and therefore, multiple herbicides in these classes of chemistry often have some activity on perennial weeds like mugwort (Senseman, 2007). Bradley and Hagood (2002) reported that the herbicide mimics of indole-3-acetic acid 2,4-D (amine or ester formulation) and triclopyr provided less than $50 \%$ control of mugwort 1 year after treatment (YAT). Other studies found that initial

\begin{tabular}{llll}
\hline $\begin{array}{l}\text { Units } \\
\begin{array}{l}\text { To convert U.S. to SI, } \\
\text { multiply by }\end{array}\end{array}$ & U.S. unit & SI unit & $\begin{array}{l}\text { To convert SI to U.S., } \\
\text { multiply by }\end{array}$ \\
\hline 0.3048 & $\mathrm{ft}$ & $\mathrm{m}$ & 3.2808 \\
0.0929 & $\mathrm{ft}^{2}$ & $\mathrm{~m}^{2}$ & 10.7639 \\
9.3540 & gal/acre & $\mathrm{L} \cdot \mathrm{ha}^{-1}$ & 0.1069 \\
2.54 & inch $(\mathrm{es})$ & $\mathrm{cm}$ & 0.3937 \\
28.3495 & $\mathrm{oz}$ & $\mathrm{g}$ & 0.0353 \\
70.0532 & $\mathrm{oz} / \mathrm{acre}$ & $\mathrm{g} \cdot \mathrm{ha}^{-1}$ & 0.0143 \\
$\left({ }^{\circ} \mathrm{F}-32\right) \div 1.8$ & $\mathrm{o} F$ & ${ }^{\circ} \mathrm{C}$ & $\left(1.8 \times{ }^{\circ} \mathrm{C}\right)+32$
\end{tabular}


control of mugwort shoot growth was possible with 2,4 -D, but regrowth would eventually occur (Ahrens, 1976; Bingham, 1965; Gouin, 1977). Bradley and Hagood (2002) also reported modest mugwort control from the branch chain amino acid inhibiting herbicide metsulfuron which targets the enzyme acetolactate synthase (Bradley and Hagood, 2002; Senseman, 2007). Glyphosate, another inhibitor of amino acid synthesis (inhibition of aromatic amino acids by targeting the enzyme 5-enol-pyruvyl-shikimate-3-phosphate synthase), provided long-term mugwort control but required repeat applications (Ahrens, 1976). However, as a non-selective herbicide, glyphosate has limited utility since it cannot be applied where it will come in contact with green tissue of desirable plants. Similarly, the glutamine synthetase inhibitor glufosinate can provide shortterm control of shoot growth but, like glyphosate, this herbicide is also nonselective and must be applied with care to minimize damage to other desirable vegetation (Bradley and Hagood, 2002; Senseman, 2007).

Picloram and clopyralid belong to the pyridine family of herbicide mimics of indole-3-acetic acid. Picloram is labeled for broadleaf weed control in pastures and non-cropland (Dow AgroSciences, 2010c). Bradley and Hagood (2002) reported 100\% control of mugwort 1 YAT with picloram applications between 280 and $1100 \mathrm{~g} \cdot \mathrm{ha}^{-1}$. Clopyralid is labeled for use in a variety of ornamental plants, specialty crops, pastures, and noncroplands (Dow AgroSciences, 2010b). Clopyralid has provided $70 \%$ to $85 \%$ mugwort control 1 YAT when applied at 150 to $300 \mathrm{~g} \cdot \mathrm{ha}^{-1}$. At rates of 280 to $2200 \mathrm{~g} \cdot \mathrm{ha}^{-1}$, clopyralid has controlled mugwort $85 \%$ to $100 \%$ (Bradley and Hagood, 2002; Day et al., 1997). Unfortunately, mugwort regrowth was observed with all treatments indicating that sequential applications may be needed for lasting control. In general, while picloram has provided better mugwort control than clopyralid, picloram has a greater potential for offsite movement and restrictions limit its use in certain states and under specific environmental conditions ( $\mathrm{Tu}$ et al., 2001).

Aminopyralid and aminocyclopyrachlor-methyl are the two most recently registered herbicides which also mimic indole-3-acetic acid, and thus, have potential for controlling difficult-to-control perennial weeds like mugwort (Turner et al., 2009). Both herbicides have demonstrated equal to or better control of key perennial weeds at lower application rates when compared with picloram and clopyralid (Enloe et al., 2007; Turner et al., 2009). Aminopyralid is a member of the pyridine family of herbicides and is registered for weed control in pasture and non-cropland areas. Aminopyralid provides weed control through both foliar and root uptake (Dow AgroSciences, 2010a). Aminocyclopyrachlor-methyl is a member of the pyrimidine family of herbicide and has been registered for non-cropland weed management. Like aminopyralid, aminocyclopyrachlor-methyl controls weeds through both foliar and root uptake (Claus et al., 2009). Currently, there are no studies that report efficacy of either aminopyralid or aminocyclopyrachlor-methyl for control of mugwort.

Mugwort is difficult-to-control and once established is difficult to eradicate (Bing and Pridham, 1963). Current industry standards can provide control, but all have limitations with regard to conditions under which they may be applied and potential environmental impacts. Aminopyralid and aminocyclopyrachlor-methyl may be potential tools to control mugwort which would require fewer applications or lower application rates than those required with current commercial standards. Therefore, the objective of this research is to determine the efficacy of aminopyralid and aminocyclopyrachlor-methyl on mugwort in comparison with the current commercial standards of picloram and clopyralid.

\section{Materials and methods}

FIELD sTUDY. Field studies were conducted at two adjacent sites in an abandoned nursery near Beersheba Springs, TN (lat. $35^{\circ} 46^{\prime} \mathrm{N}$, long. $\left.85^{\circ} 65^{\prime} \mathrm{W}\right)$. These sites were abandoned due to the competitiveness of the mugwort populations with previous nursery plantings. The soil type at these sites was a Beersheba loam with pH 5.8 and $2.2 \%$ organic matter. Research plots were established $10 \times$ $20 \mathrm{ft}$ in size with three replications. POST treatments were applied at both study sites on 7 May 2008 with a carbon dioxide $\left(\mathrm{CO}_{2}\right)$-powered backpack-sprayer calibrated to deliver 23 gal/acre. Since we discovered two large tracts of abandoned land that contained mugwort as the predominant vegetation; we decided to use both tracts as two separate studies in the same year. Our reason for treating the second location in the same time period was a desire to rapidly initiate treatment to reclaim this land for grower production as soon as possible. Treatments applied to both studies included aminocyclopyrachlor-methyl (DPX-KJM44; DuPont Crop Protection, Wilmington, DE) at 70, 140, and $280 \mathrm{~g} \cdot \mathrm{ha}^{-1}$ a.i., aminopyralid (Milestone; Dow AgroSciences, IN) at 70,140 , and $280 \mathrm{~g} \cdot \mathrm{ha}^{-1}$ a.i., clopyralid (Transline, Dow AgroSciences) at 280 $\mathrm{g} \cdot \mathrm{ha}^{-1}$ a.i., and picloram (Tordon, Dow AgroSciences) at $280 \mathrm{~g} \cdot \mathrm{ha}^{-1}$ a.i. All treatments included methylated seed oil (Universal Crop Protection Alliance, Eagan, MN) at a rate of $1 \% \mathrm{v} / \mathrm{v}$. The established mugwort population had an average height of $23 \mathrm{~cm}$ at the time of application. Sethoxydim (Poast; BASF Ag Products, Research Triangle Park, NC) was applied at $420 \mathrm{~g} \cdot \mathrm{ha}^{-1}$ a.i. on 3 June 2008, and glyphosate (Touchdown Total; Syngenta Crop Protection, Greensboro, NC) at $2335 \mathrm{~g} \cdot \mathrm{ha}^{-1}$ a.i. plus a premix of atrazine at 1823 $\mathrm{g} \cdot \mathrm{ha}^{-1}$ a.i. plus metolachlor (Bicep II Magnum, Syngenta Crop Protection) at $1411 \mathrm{~g} \cdot \mathrm{ha}^{-1}$ a.i. were applied on 28 July 2008 to control other weeds present after aminocyclopyrachlormethyl, aminopyralid, picloram, and clopyralid treatments were applied in the studies. The purpose of applying these maintenance treatments to all plots (including the control plots) was to eliminate competition from other weeds to solely focus on how our treatments impacted these mugwort populations. Rates of each product were selected that would adequately control the annual weeds present while not significantly inhibiting the growth of a perennial weed like mugwort (Robinson et al., 2003; Senseman, 2007).

Percent control ratings were taken at 56 and $365 \mathrm{~d}$ after treatment, whereby 0 indicated no control and 100 indicated complete control. Stand counts of mugwort were also recorded at 82 and 365 DAT out of two $0.25-\mathrm{m}^{2}$ areas randomly selected in each plot, and dry weights (DW) of shoot biomass were acquired from those same areas at 365 DAT. Heights of mugwort plants were taken at three random points within the $0.25-\mathrm{m}^{2}$ areas 
and an averaged for comparison across plots.

GreENHOUSE STUdy. Greenhouse studies were conducted in Knoxville, TN (lat. $35^{\circ} 58^{\prime} \mathrm{N}$, long. $85^{\circ} 55^{\prime} \mathrm{W}$ ) and repeated in time. Mugwort rhizomes were collected from the Beersheba Springs location and were trimmed into 1 -inch-long segments. Five of these mugwort rhizome segments were planted in $10-\mathrm{cm}$-diameter pots containing Sequatchie loam soil (fineloamy, siliceous, semiactive, thermic humic Hapludult), with pH 6.2 and $2.1 \%$ organic matter content. This soil was mixed with a calcined clay based soil conditioner (Turface MVP; Turface Athletics, Fenton, MO) in a 3:1 soil-to-conditioner ratio to enhance drainage. Treatments included aminocyclopyrachlor-methyl and aminopyralid each at 70 and $140 \mathrm{~g} \cdot \mathrm{ha}^{-1}$ each mixed with a methylated seed oil surfactant at $1 \% \mathrm{v} / \mathrm{v}$. Treatments were applied in two separate runs each containing four replications on 14 July 2008 with a $\mathrm{CO}_{2}$-pressurized backpack-sprayer calibrated to deliver 215 $\mathrm{L} \cdot \mathrm{ha}^{-1}$. Mugwort plants averaged $9 \mathrm{~cm}$ in height at the time of herbicide application. Plants were fertilized with 20N-8.7P-16.6K water-soluble fertilizer (Plantex 20-20-20; Plant Products Co., Brampton, ON, Canada) and watered as needed to encourage maximize mugwort growth and overall plant vigor.

Percent control ratings were visually assessed at 28 DAT with the same $0 \%$ to $100 \%$ scale used in our field studies. After assessing mugwort control, shoot growth was harvested from each pot by removing all plant matter from above the soil surface. Regrowth was assessed at 60 DAT; whereby any remaining aboveground biomass was harvested and dried to similar moisture content. Mugwort biomass in the field and greenhouse studies was dried in a drying oven for $48 \mathrm{~h}$ at $51{ }^{\circ} \mathrm{C}$.

Statistical analysis. Field and greenhouse trials were arranged in a randomized complete block design. Analysis of variance was applied to all data in the field and greenhouse studies using PROC GLM in SAS (version 9.1; SAS Institute, Cary, NC). Arcsine square root function was used to transform visual weed control data, and Fisher's protected least significant difference test $(P=0.05)$ was used for mean separation on all data. Data were pooled when study by treatment interactions were not significant.

\section{Results and discussion}

Experimental run-by-treatment interactions were not significant for any data in these trials; therefore, data from each experimental run of the field and greenhouse studies were combined.

Field study. Aminopyralid at 140 and $280 \mathrm{~g} \cdot \mathrm{ha}^{-1}$ and aminocyclopyrachlor-methyl at $280 \mathrm{~g} \cdot \mathrm{ha}^{-1}$ provided $84 \%$ to $94 \%$ control of mugwort by 56 DAT (Table 1). In contrast, picloram and clopyralid at $280 \mathrm{~g} \cdot \mathrm{ha}^{-1}$ provided $73 \%$ and $38 \%$ control by 56 DAT, respectively. By 365 DAT, both aminopyralid and aminocyclopyrachlormethyl at 140 and $280 \mathrm{~g} \cdot \mathrm{ha}^{-1}$ controlled mugwort over $90 \%$, whereas the control exhibited by picloram and clopyralid remained virtually unchanged at $75 \%$ and $31 \%$, respectively.

By 82 DAT, mugwort stand counts were reduced by $68 \%$ to $100 \%$ with aminocyclopyrachlor-methyl, aminopyralid, and picloram treatments (Table 1). Clopyralid reduced mugwort stand counts by $60 \%$. By 365 DAT, stand counts were reduced $67 \%$ to $100 \%$ with aminopyralid, aminocyclopyrachlor-methyl, and picloram treatments. In contrast, clopyralidtreated plots contained $29 \%$ more mugwort plants than the untreated control by 365 DAT (Table 1). Mugwort heights and DW biomass were reduced by $90 \%$ to $100 \%$ by 365 DAT with aminopyralid and aminocyclopyrachlor-methyl applied at $140 \mathrm{~g} \cdot \mathrm{ha}^{-1}$ or greater. Mugwort heights and DW biomass were only reduced $31 \%$ to $57 \%$ when aminopyralid or aminocyclopyrachlor-methyl rates were reduced to $70 \mathrm{~g} \cdot \mathrm{ha}^{-1}$. Picloram reduced mugwort height by $73 \%$ and DW biomass by $85 \%$. Clopyralid reduced mugwort height by $10 \%$ and increased mugwort DW biomass by $13 \%$.

Picloram efficacy in our studies was lower than reported in other studies where mugwort was controlled by at least 95\% (Bradley, 2000; Bradley and Hagood, 2002). Many factors can impact picloram efficacy, including precipitation, soil composition, and plant maturity (Bovey et al., 1968, 1978; Gaynor and Volk, 1976; Glass, 1974; Klingaman and Ashton, 1982; Ross and Lembi, 1985). Picloram efficacy

Table 1. Visual control ratings for mugwort at 56 and $365 \mathrm{~d}$ after treatment (DAT), stand counts at 82 and 365 DAT, and height and shoot regrowth dry weight biomass at 365 DAT for mugwort treated with aminocyclopyrachlor-methyl, aminopyralid, picloram, and clopyralid in the field.

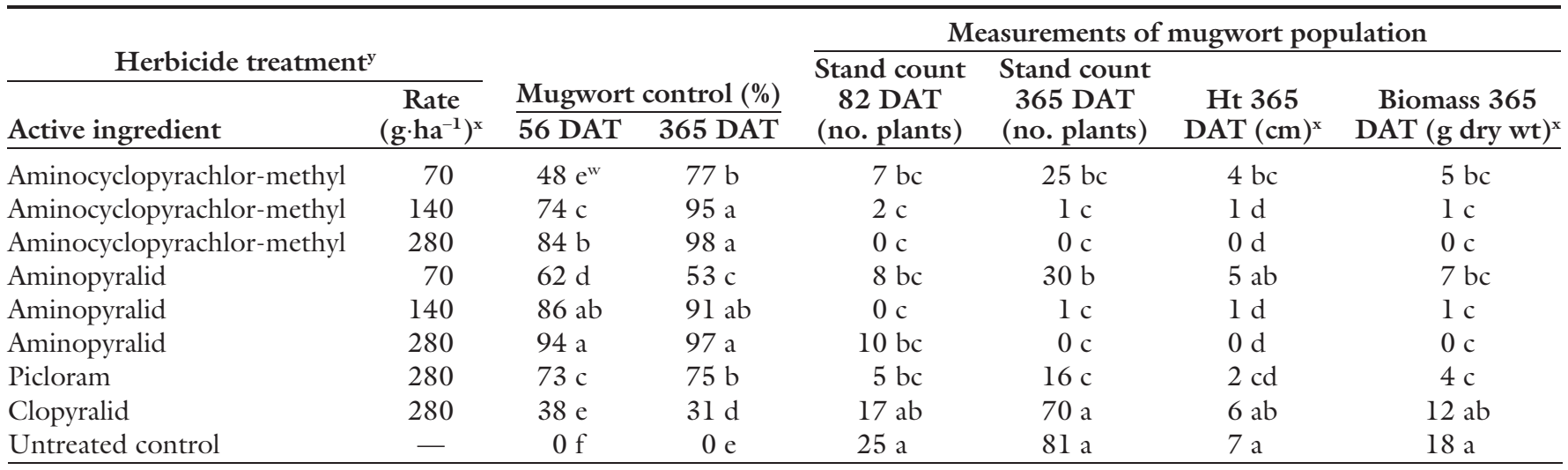

${ }^{2}$ No study by treatment interactions occurred for any mugwort data; therefore, these data were pooled over studies.

yAll treatments included a $1 \%(\mathrm{v} / \mathrm{v})$ methylated soybean oil adjuvant.

${ }^{\mathrm{x}} \mathrm{l} \mathrm{g} \cdot \mathrm{ha}^{-1}=0.0143 \mathrm{oz} /$ acre, $\mathrm{l} \mathrm{cm}=0.3937 \mathrm{inch}, \mathrm{lg}=0.0353 \mathrm{oz}$.

"Within columns, means followed by the same letter are not significantly different, according to Fisher's protected least significant difference test at $P=0.05$. 
Table 2. Visual control ratings at $28 \mathrm{~d}$ after treatment (DAT) and shoot dry weight biomass at 28 and 60 DAT for mugwort treated with postemergence applications of aminocyclopyrachlor-methyl and aminopyralid in the greenhouse. ${ }^{\mathrm{z}}$

\begin{tabular}{|c|c|c|c|c|}
\hline \multicolumn{2}{|c|}{ Herbicide treatment $\mathrm{t}^{\mathrm{y}}$} & \multirow{2}{*}{$\begin{array}{l}\text { Mugwort control } \\
28 \text { DAT }(\%)\end{array}$} & \multirow{2}{*}{$\begin{array}{l}\text { Mugwort biomass } \\
28 \text { DAT }(\mathrm{g} \text { dry wt) } \\
\end{array}$} & \multirow{2}{*}{$\begin{array}{c}\text { Mugwort re-growth } \\
\text { biomass } 60 \text { DAT (g dry wt) }\end{array}$} \\
\hline Active ingredient & Rate $\left(\mathrm{g} \cdot \mathrm{ha} \mathrm{a}^{-1}\right)^{\mathrm{x}}$ & & & \\
\hline Aminocyclopyrachlor-methyl & 70 & $79 c^{w}$ & $1.33 \mathrm{~b}$ & $0 \mathrm{~b}$ \\
\hline Aminocyclopyrachlor-methyl & 140 & $92 \mathrm{~b}$ & $1.14 \mathrm{~b}$ & $0 \mathrm{~b}$ \\
\hline Aminopyralid & 70 & $94 \mathrm{ab}$ & $0.92 \mathrm{bc}$ & $0 \mathrm{~b}$ \\
\hline Aminopyralid & 140 & 96 a & $0.62 \mathrm{c}$ & $0 \mathrm{~b}$ \\
\hline Untreated control & - & $0 \mathrm{~d}$ & $3.42 \mathrm{a}$ & $0.68 \mathrm{a}$ \\
\hline
\end{tabular}

${ }^{\mathrm{z}}$ No study by treatment interactions occurred for any mugwort data; therefore, these data were pooled over studies.

yAll treatments included a $1 \% \mathrm{v} / \mathrm{v}$ methylated soybean oil adjuvant.

${ }^{\mathrm{x}} \mathrm{l} \mathrm{g} \cdot \mathrm{ha} \mathrm{a}^{-1}=0.0143 \mathrm{oz} / \mathrm{acre}, \mathrm{l} \mathrm{g}=0.0353 \mathrm{oz}$.

"Within columns, means followed by the same letter are not significantly different, according to Fisher's protected least significant difference test at $P=0.05$.

reported by Bradley (2000) and Bradley and Hagood (2002) was observed when this treatment was applied to a Leaf silt loam (clayey, mixed, thermic Typic Abaquults) soil with 1.5\% organic matter, whereas our studies were conducted on a Beersheba loam (Loamy residuum weathered from sandstone) with $2.2 \%$ organic matter. Our trial sites received $6.25 \mathrm{~cm}$ of rain within the $10 \mathrm{~d}$ following herbicide application (data not reported), which could have potentially impacted the ability of mugwort to absorb picloram through the roots. Since the Beersheba loam soil in our studies should have better drainage than a Leaf silt loam soil reported in the studies by Bradley (2000) and Bradley and Hagood (2002), it is possible that the picloram may have been less available for absorption by mugwort rhizomes because of its rapid movement through the soil profile by rain (Herr et al., 1966).

Mugwort control with clopyralid in our studies was consistent with a previous trial done in the same abandoned nursery (Robinson et al., 2003), however, control in our studies and those by Robinson et al. (2003) was less than observed by Day et al. (1997) who reported $70 \%$ to $85 \%$ control of mugwort with similar rates of clopyralid. Because clopyralid, like picloram, is very mobile in soils and does not bind strongly with soil particles it is possible that rainfall could have similarly impacted its performance on mugwort (Cox et al., 1996). Aminopyralid, the other pyridine mimic of indole-3-acetic acid herbicide evaluated in this study, has greater soil adsorption potential in comparison with picloram and clopyralid and may explain why it provided greater efficacy on mugwort in comparison with these similar herbicides (Fast et al., 2010).
GreenHouse STUdy. By 28 DAT, aminopyralid applied at 70 and 140 $\mathrm{g} \cdot \mathrm{ha}^{-1}$ controlled mugwort $94 \%$ and $96 \%$, respectively (Table 2 ). In addition, aminocyclopyrachlor-methyl applied at $140 \mathrm{~g} \cdot \mathrm{ha}^{-1}$ controlled mugwort 92\%; however, $70 \mathrm{~g} \cdot \mathrm{ha}^{-1}$ of aminocyclopyrachlor-methyl only controlled mugwort $79 \%$. Compared with the untreated control, all treatments reduced the DW of mugwort biomass at 28 DAT by $60 \%$ to $82 \%$. No regrowth was observed with any treatment by 60 DAT.

In both field and greenhouse trials, aminocyclopyrachlor-methyl and aminopyralid provided excellent control of mugwort and impaired regrowth of this weed. Observed levels of mugwort control were better than that achieved using the current commercial standards, clopyralid and picloram. We conclude that aminopyralid and aminocyclopyrachlor-methyl have potential to provide excellent control of mugwort compared with clopyralid and picloram in non-cropland areas or in the case of our research as part of a reclamation project in abandoned nurseries. Future research should evaluate whether multiple years of aminopyralid or aminocyclopyrachlor-methyl treatments could be used to eradicate mugwort from an infested area and what types of replant restrictions would be required for safe reestablishment of nursery stock following these types of applications.

\section{Literature cited}

Ahrens, J.F. 1976. Chemical control of Artemisia vulgaris in ornamentals. Proc. Northeastern Weed Sci. Soc. 30:303307. (abstr.).

Barney, J.N., A.G. Hay, and L.A. Weston. 2005. Isolation and characterization of allelopathic volatiles from mugwort (Artemisia vulgaris). J. Chem. Ecol. 31:247-265.
Bing, A. and A.M.S. Pridham. 1963. Field trials for control of Artemisia vulgaris L. Proc. Northeastern Weed Sci. Soc. 17:202. (abstr.).

Bingham, S.W. 1965. Chemical control of mugwort. Weeds 13:239-242.

Bovey, R.W., F.S. Davis, and H.L. Morton. 1968. Herbicide combinations for woody plant control. Weeds 16:332-335.

Bovey, R.W., C. Richardson, E. Burnett, M.G. Merkle, and R.E. Meyer. 1978. Loss of spray and pelleted picloram in surface runoff water. J. Environ. Qual. 7:178-180.

Bradley, K.W. 2000. Characterization of the mechanism of resistance of a johnsongrass (Sorghum halepense) biotype to selected graminicides in Virginia and response of mugwort (Artemisia vulgaris) to specific herbicidal and cultural control strategies. Virginia Polytechnic Inst., Blacksburg, PhD Diss.

Bradley, K.W. and E.S. Hagood, Jr. 2002. Evaluations of selected herbicides and rates for long-term mugwort (Artemisia vulgaris) control. Weed Technol. 16: 164-170.

Claus, J.S., M.J. Holliday, R.G. Turner, J.H. Meredith, and C.S. Williams. 2009. Aminocyclopyrachlor development and registration update. Proc. North Central Weed Sci. Soc. 64:128. (abstr.).

Cox, L., A. Walker, M.C. Hermosin, and J. Cornejo. 1996. Measurement and simulation of the movement of thiazafluron, clopyralid and metamitron in soil columns. Weed Res. 36:419-429.

Danielson, L.L. 1965. Herbicidal effects of sodium and potassium azides on mugwort. Weeds 13:96-98.

Day, M.Y., E.S. Hagood, Jr., and S.M. Johnson. 1997. Evaluation of herbicide programs for mugwort control in corn. Proc. Northeastern Weed Sci. Soc. 51:34. (abstr.).

Dow AgroSciences. 2010a. Milestone label. 28 July 2010. <http://www.cdms.net/ ldat/ld02P012.pdfs. 
Dow AgroSciences. 2010b. Stinger label. 3 Mar. 2010. <http://www.cdms.net/ ldat/ld77N006.pdf>.

Dow AgroSciences. 2010c. Tordon 22K label. 3 Mar. 2010. <http://www.cdms. net/ldat/ld0AJ013.pdf>.

Enloe, S.F., R.G. Lym, R. Wilson, P. Westra, S. Nissen, G. Beck, M. Moechnig, V. Peterson, R.A. Masters, and M. Halstvedt. 2007. Canada thistle (Cirsium arvense) control with aminopyralid in range, pasture, and noncrop areas. Weed Technol. 21:890894.

Fast, B.J., J.A. Ferrell, G.E. MacDonald, L. Jason Krutz, and W.N. Kline. 2010. Picloram and aminopyralid sorption to soil and clay minerals. Weed Sci. 58:484489.

Gaynor, J.D. and V.V. Volk. 1976. Surfactant effects on picloram adsorption by soils. Weed Sci. 24:549-552.

Glass, B.L. 1974. Picloram in lysimeter runoff and percolation water. Bull. Environ. Contam. Toxicol. 11:109-112.
Gouin, F.R. 1977. Controlling rip-shins (brambles) and mugwort with glyphosate. Proc. Northeastern Weed Sci. Soc. 31:328. (abstr.).

Herr, D.E., E.W. Stroube, and D.A. Ray. 1966. The movement and persistence of picloram in soil. Weeds 14:248-250.

Holm, L., J. Doll, E. Holm, J. Pancho, and J. Herberger. 1997. World weeds: Natural histories and distribution. Wiley, New York.

Klingaman, G.C. and F.M. Ashton. 1982. Weed science: Principles and practices. 2nd ed. Wiley, New York.

Klingeman, W.E., D.K. Robinson, and G.L. McDaniel. 2004. Regeneration of mugwort (Artemisia vulgaris) from rhizome sections in sand, pine bark, and soil substrates. J. Environ. Hort. 22:139-143.

Pawlowski, F., J. Kapeluszny, A. Kolasa, and Z. Lecyk. 1967. Fertility of some species of ruderal weeds. Annales Universitatis Mariae Curie-Sklodowska LublinPolonia 22(15):221-231.
Robinson, D.K., D. Fare, and M. Halcomb. 2003. Wild chrysanthemum (Artemisia vulgaris L.) management in fallow land prior to ornamental plant production. HortScience 38(6):1277. (abstr.).

Rogerson, A.B. 1964. A study of mugwort. I. Growth habits and control. II. Effects of 2,3,6-trichlorophenylacetic acid on certain respiratory enzymes. Virginia Polytechnic Inst., Blacksburg, MS Thesis.

Ross, M.A. and C.A. Lembi. 1985. Applied weed science. Burgess Publ., Minneapolis.

Senseman, S.A. 2007. Herbicide handbook. 9th ed. Weed Sci. Soc. Amer., Lawrence, KS.

Tu, M., C. Hurd, and J.M. Randall. 2001. Weed control methods handbook. 27 July 2011. <http://www.invasive.org/gist/ handbook.html>.

Turner, R.G., J.S. Claus, E. Hidalgo, M.J. Holliday, and G.R. Armel. 2009. Technical introduction of the new DuPont vegetation management herbicide aminocyclopyrachlor. Proc. Weed Sci. Soc. Amer. 49:405. (abstr.). 